\title{
CLASSIFICATION OF "VARIETIES» OF PASTEURELLA PESTIS STRAINS ISOLATED IN THE INTERIOR OF THE STATE OF PERNAMBUCO-BRAZIL
}

\author{
Dalva A. Mello * and Laura M. Vasconcelos **
}

\begin{abstract}
Studies were made on the biochemical behavior of 100 strains of $\mathbf{P}$. pestis isolated in Northeastern Brazil with regard to production of nitrous acid, reduction of nitrates to nitrites, and acidification of glycerol. Results showed that 98 strains can be classified as "orientalis variety", while the remaining two could not be included in any of the existing "varieties".
\end{abstract}

\section{INTRODUCTION}

It is known that production of nitrous acid, reduction of nitrates to nitrites, and acidification of glycerol has no diagnostic value in regard to identification of Pasteurella pestis. However, such laboratory tests are useful for differentiation of the so-called "geographical races" of the plague bacillus (10) .

In 1928 the Russian investigator, Bezsonova (4) for the first time called attention to the biochemical variability of strains of $P$. pestis. Strains isolated in India did not attack the glycerol, while those isolated in southeastern Russia did so.

Furthermore, Kurauchi (7) and Berlin \& Borzenkov (3) were able to distinguish two "races" of $P$. pestis; they named these "continental", which acidified the glycerol, and "oceanic" which did not attack glycerol.

In 1949 Devignat $(5,6)$, while studying the above mentioned "races" with regard to the production of nitrous acid, proposed a new classification for what he called "varieties" of $P$. pestis. He recognized three "varieties": (1) "orientalis", which reduced nitrates but did not attack the glycerol; (2) "antiqua", which attacked the glycerol and reduced nitrates to nitrites; and (3) "medievalis", which produced acid in glycerol but not reduced nitrates to nitrites.

In 1941 Machiavello $(7,8)$ studied 45 strains of $P$. pestis isolated in Brazil, all of which were unable to attack the glycerol.

The present study was undertaken with special interest of knowing more about the Brazilian strains of $P$. pestis and to relate them to the already described "varieties" of the plague bacillus.

\section{MATERIAL AND METHODS}

The 100 strains of $P$. pestis employed in this study were isolated during epidemic and epizootic outbreaks of plague occurr-

\footnotetext{
* Biologista do Centro de Pesquisas Aggeu Magalhāes (I.N.E.Ru.) Recife - Pernambuco e Bolsista do Centro Regional de Investigação e Ensino em Saúde Pública (SUDENE-U.F.Pe.). $\because$ Biologtsta do Centro de Pesquisas Aggeu Magalhães (I.N.E.Ru.) Recife-Pe. Adress: I.B.T.M., Caixa Postal 1859, Rio, Guanabara.
} 
ing in the interior of the state of Pernambuco-Brazil, in the year of 1966 and 1967. Sixteen of those strains were isolated from humans, 59 from wild rodents, and 25 from rodent fleas.

The following biochemical tests controls were employed as (a) a strain of Sthaphylococus aureus for the reduction of nitrates to nitrites; and (b) a blank test for production of just acid nitrous.

The preparation of the culture media and reagents as well as the conduction of the tests were made in strict conformity to the methods of Baltazard et al. (2) in a paper produced in 1956 .

\section{RESULTS}

From the 100 strains of $P$. pestis studied, 98 were capable of producing nitrous acid and of reducing nitrates to nitrites.

According to the classification of Devignat $(5,6)$ the 98 strains of $P$. pestis studied in this paper should be placed among the "orientalis variety" while the remaining two strains could not be included in any of the others "varieties".

The controls behaved as expected.

\section{DISCUSSION}

Results presented in the current paper show that 98 strains of $P$. pestis isolated in Northeastern Brazil belong to the "orientalis variety" according to the classification of Devigant $(5,6)$ or to the "oceanic race" of Kurauchi (7), Berlin \& Borzenkow (3) and Pollitzer (9).

In view of the uniform biochemical pattern presented by great majority of the strains, the remaining two strains might represent mutants which became unable to reduce nitrates and to produce nitrous acid.

The majority of specialists agree (without any reasonable explanations) that the strains of $P$. pestis which have been introduced in virgin countries by sea route belong to the "orientalis variety" or "oceanic race".

It is known that Plague was introduced in Brazil by sea route via the port of Santos in 1899, five years after the pandemic occurred in Hong-Kong (1) .

Results obtained in this paper as well as those of Machiavello $(7,8)$ give additional strength to the idea the strains introduced by sea route belong to the "orientalis variety".

\section{RESUMO}

Os autores estudaram o comportamento bioquimico de 100 amostras de P. pestis isoladas no Nordeste do Brasil em relação ao glicerol, produção de ácido nitroso, e redução de nitratos a nitritos. Encontraram $98 \%$ das amostras pertencendo à "variedade orientalis" e $2 \%$ não enquadradas em nenhuma classificação das chamadas "variedades geogrảficas" de P. pestis.

\section{REFERENCES}

1. ARCOVERDE, C.F. - Notícia sôbre a peste no Nordeste. Rev. Bras. Mal. e Doen. Trop. 9: 123-133, 1957.

2. BALTAZARD, M., DAVID, D.M.S., DEVIGNAT, R., GIRARD, G., GOHAR M.A., KARTMAN, L., MEYER, K.F., PARKER, M.T., POLLITZER, R. PRINCE, F.M., QUAN, S.F., WAGLE, P. - Recomended laboratory Methods for Diagnosis of Plague. Bull. Wld. Hith. Org. 14: 457-509. 1965.

3. BERLIN, A.L. \& BORSENKOV, A.K., $(1938)$ in POLLITZER, R. - Plague
World Health Organization, Monograph Serie N. 22 . - Palais des Nations - Geneve, 1954.

4. BEZSONOVA, A. (1928) in POLLITER R. - Plague "World Health Organization. Monograph Series N.O 22. Palais des Nations. Geneve, 1954.

5. DEVIGNAT, R. - La prophylaxie de la peste au Lac Albert par l'association de la Deratisation et de la Vaccination (virus-vacin EV de Girard Robic) Bull. Soc. Path. Exot. 42: 43-52. 1949. 
6. DEVIGNAT, $R$. et BOIVIN, $A$. Deux millieux complexes pour la differentiation des trois variètes de Pasteurella pestis et de Pasteurella pseudotuberculosis. Bull. Soc. Path. Exot. 46: 627-631, 1953.

7. KURAUCHI, K. (1937) in POLLITZER, R. - Plague World Health Organization Monograph Series. N.o 22. Palais des Nations. Geneve 1954.

8. MACHIAVELLO, A. - Estudio sobre variación bacteriana de la Pasteurella pestis com especial referencia a variaciones en morfologia, caracteres de las colonias, virulencia, toxicidad $y$ propriedade bioquimicas. Arq. Hig. 11: 73-102, 1941.

9. MACHIAVELLO, A. - Bacteriologia general de la peste bubonica observada en el Nordeste brasileño. Arq. Hig. 11: 53-65, 1941.

10. POLLITZER, R. - Classification de la peste par des methodes biochimiques. Etat des connaissances et orientation des recherches futures. Bull. Wld. Hth. Org. 9, 655-662, 1953.

11. POLLITZER, R. - Plague. World Health Organization: Monograph. Series n.$^{\circ} 22$. Palais des Nations. Geneve, 1954. 